\title{
In Memoriam Szabó János
}

Egy megkerülhetetlen ember

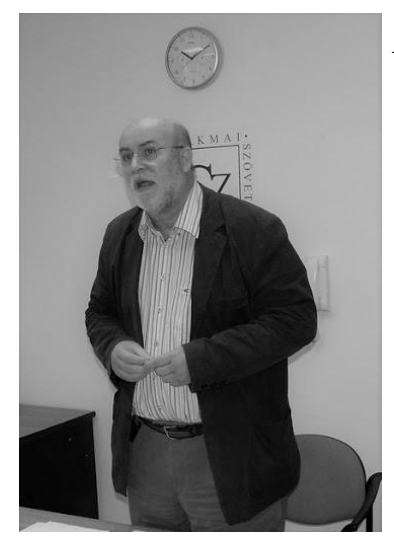

A gyász még bennünk él, nehéz szavakat formálni egy jó barátról, egy

kollégáról, aki váratlanul, nagyon gyorsan és csendesen távozott.

Szabó János szakmai életútja igen sokunkra volt közvetlen vagy közvetett hatással.

Szociális szervező, majd szociológus-szociálpolitikus egyetemi oklevelet szerzett. Olyan oktatói és csoporttársai voltak, akik jelentős hatással voltak szemléletmódjára és munkásságára. Pályafutását az egészségügyben kezdte, majd a Vöröskereszt következett, 1988-ban alapította meg a „Kaposvári Családsegítő Központot”, amelyet nyugdíjba vonulásáig vezetett. A semmiből teremtett egy országos hírü módszertani intézményt. Az Ö keze munkáját dicséri a város szociális ellátórendszerének teljes kiépítése, fejlesztése. A város szociálpolitikájának meghatározó személye volt. A kollégái nagyon tisztelték, szerették, nyugdíjazásakor az intézmény „örökös igazgatója” címet adományoztak neki. Igazi „munkamániásnak” nevezték. Szabadsága alatt is sokat dolgozott, vagy az éjszaka is a munkahelyén találta. Nagyon szerette a szakmáját. Folyamatosan törekedett arra, hogy a város és az intézmény olyan új és innovatív szolgáltatásokat tudjon nyújtani, amely hozzájárul a kaposvári lakosok életminőségének javításához. Igazi terepmunkás volt. A Kaposvárhoz kötődő tevékenysége vélhetően feldolgozásra fog kerülni.

Országos szinten való munkássága tette igazán ismertté.

Az Eötvös Lóránd Tudományegyetem, illetve a Pécsi Tudományegyetem óraadó tanára volt. Szakmapolitikai tevékenysége elismeréseként 2005-2010. között az Országos Szociálpolitikai Tanács társelnöki feladatát látta el.

Választott tisztségeket töltött be a Szociális Szakmai Szövetségben, melynek hosszabb ideig ügyvivője, alelnöke volt. Ez az időszak nevezhető a 3SZ aranykorának. A Magyar Családsegítő és Gyermekjóléti Szolgálatok Országos Egyesületének megalakulásától haláláig ügyvezető alelnöke.

Tagja volt az Euro-Régió Szociális Szakmai Közösség Egyesületnek, a Gyermekjóléti és Gyermekvédelmi Ellátások Országos Szakmai Kollégiumának.

Huzamos ideig az Országgyülés Népjóléti Szakbizottságának, illetve Kaposvár Város szakbizottságának szakértői feladatkörét látta el. 


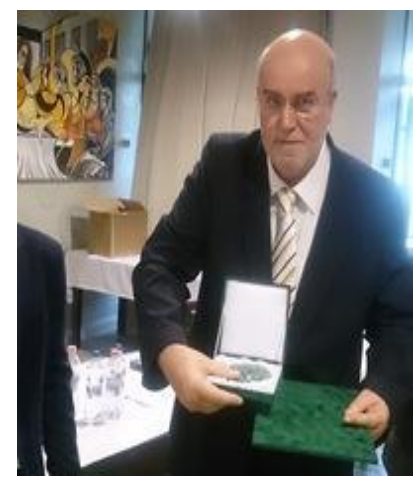

Munkáját mindenki elismerte, Lovagkereszt és Pro Caritate

kitüntetéseket vehetett át. Nyugdíjba vonulása után is szívén viselte a család- és gyermekjóléti szolgálatok sorsát. Élete végéig vezette azt a hálózati munkát, amely a család és gyermekjóléti szolgálatok fejlesztését célozza meg. Utolsó nagy szakmai fejlesztése a szociális vezetőképzés előkészítése és a sikeres elindításának támogatása volt. A Semmelweis Egyetem Szociális Vezetőképzése mentortestületének alaptagja volt.

Az általa vezetett intézményben keze alatt több olyan szakember „nevelkedett”, aki később helyben, az ország más szegletében vagy épp központi hivatalban vezető munkakörben folytatta tovább pályafutását.

Támogatta kollégái fejlődését, lehetőséget biztosított képzésükre, elismerte tudásukat. Számos esetben delegálta őket külső szervekkel való tárgyalásra vagy éppen bevonta a saját maga által végzett szakmai, közéleti tevékenységbe. Büszke volt munkatársaira, intézményére.

János intézményvezetői feladatai mellett folyamatosan alkotott, döntéselőkészítést szolgáló háttéranyagokat készített, publikált, szakmai közéleti eseményekre járt.

Egyetlen értekezlet sem kezdődött el a Minisztériumban vagy a Tüzér utcában, amíg meg nem érkezett.

Bármilyen feladatot kapott, azt határidőre és a lehető legnagyobb precizitással készítette el. Jogászokat meghazudtoló módon írt jogszabály-módosítást előkészítő anyagokat, vagy épp véleményezett jogszabálytervezeteket. Közgazdászi alapossággal készített elemzéseket és végzett számításokat, ügyvédeket meghazudtoló módon tudott érvelni és kiállni álláspontja mellett.

A munka és a kötelesség volt számára az első és ez éltette. Amikor tavaly az egészségi állapota megromlott, akkor is - bár lassított ütemben és családja támogatásával - dolgozott. Levezényelte a MACSGYOE éves tanácskozását, eljárt munkamegbeszélésekre és szakmai anyagokat állított össze.

Számtalan alkalommal szakértett országos rádió és televízió müsorokban.

A helyi sajtó állandó és ismert szereplője volt, így aki személyesen nem ismerte, az is megismerhette, mert bármilyen társadalmi probléma került terítékre, arról Szabó János szociológust interjúvolta meg a televízió és a helyi hírlap. 2009-ben egy portugál tanulmányút során is a képes volt a helyi napilap címlapjára felkerülni.

János szociológus, szociálpolitikus, de mindenekelőtt szociális munkás volt. Bármilyen szerepkörben jelent meg sokféle funkciója között, mindig a nehéz sorsú, szükséget szenvedő, bajban levő emberek érdekeiért való kiállás volt a vezérlő motívuma. Rendkívüli módon látta át a rendszerek, szervezetek közötti összefüggéseket a szociális terület teljes vertikumában. Egyaránt szót tudott érteni akár a bürokráciával, a kormányzattal, a civilekkel, vagy a 
klienseivel. Bárhol is jelent meg, mindenki figyelme azonnal őrá irányult. És nem a termete, megjelenése okán, hanem a rendszerezésre képes gondolatai, a gyors átlátó, konszenzusteremtő képessége miatt. Mindezek mellett megmaradt egy érzékeny lelkületű segítőnek, gondoskodó apának, bár ezt a felületes szemlélő nem vette észre. Érzelmeit csak azoknak mutatta meg, akik közel kerültek hozzá.

Ö volt az, aki a szakma érdekeinek képviselete, fejlesztése érdekében politikai nézettől függetlenül képes volt szót érteni, párbeszédet folytatni valamennyi kormánnyal, és minden más szervezettel. E tekintetben is nagy ürt hagyott maga után.

Már most is nagyon érzékelhető hiánya a szociális szakmai közéletből. Tekintélyével talán Ö volna képes összefogni a töredező szakmánkat.

A megemlékezést készitette: Erdős Zsuzsanna és Takács Imre 